\title{
Terapia Gênica e Doping Genético: Diálogos Bioéticos e Biojurídicos
}

Tiago Vieira Bomtempo

\begin{abstract}
Resumo: A aplicação da engenharia genética no esporte desperta o debate com a criação dos atletas geneticamente modificados, a partir do doping genético. Nesse sentido, busca-se nestes estudos abordar o melhoramento genético no esporte, apresentando seus principais questionamentos bioéticos e bio-jurídicos. Para tanto, pesquisou-se autores em Biodireito, Bioética, Filosofia e em Genética, dado o caráter interdisciplinar que o tema exige. Assim, apresentou-se a distinção entre tratamento e melhoramento, com a terapia gênica e o doping genético, e, em seguida, adentrou-se nas questões bioéticas e jurídicas que o objeto da pesquisa envolve, de forma que, para ao final, o leitor possa refletir quais serão os impactos da genética aplicada ao rendimento esportivo e na sociedade. Os resultados desta pesquisa permitem concluir que a evolução é inerente ao homem, contudo, quando se trata da alteração genômica, torna-se imperiosa a reflexão dos impactos do aperfeiçoamento genético de forma a garantir iguais liberdades fundamentais no contexto do Estado Democrático de Direito. Com essa abordagem demonstra-se que a bioética é o eixo do diálogo e debate multidisciplinar que o tema envolve para a construção dos novos rumos da engenharia genética humana.
\end{abstract}

Palavras-chave: Doping. Engenharia genética; Bioética; Direito; Democracia

Data de recebimento: 25 de julho de 2018

Data de aceitação: 26 de novembro de 2018
Data de avaliação: 28 de agosto de 2018

Publicação online: 19 de dezembro de 2018

Cómo citar: Bomtempo, T. V. (2019). Terapia Gênica e Doping Genético: diálogos bioéticos e biojurídicos. Revista Latinoamericana de Bioética, 19(36-1). https://doi.org/10.18359/rlbi.3583

a Mestrado em Direito Privado, Estudante de doutorado, Universidade Federal de Minas Gerais, Belo Horizonte, Brasil.

Correo electrónico: tiagodoutorado@ufmg.br

ORCID: https://orcid.org/0000-0002-8877-4152 


\section{Terapia génica y doping genético: diálogos bioéticos y biojurídicos}

Resumen: La aplicación de la ingeniería genética en el deporte despierta el debate con la creación de los atletas genéticamente modificados, a partir del dopaje genético. En este sentido, se busca en estos estudios abordar el mejoramiento genético en el deporte, presentando sus principales cuestionamientos bioéticos y biojurídicos. Para tanto, se investigó autores en Bioderecho, Bioética, Filosofía y Genética, dado el carácter interdisciplinar que el tema exige. Así, se presentó la distinción entre tratamiento y mejoramiento, con la terapia génica y el dopaje genético, y, enseguida, se centró en las cuestiones bioéticas y jurídicas que el objeto de la investigación involucra, de forma que, para al final, el lector pueda reflexionar sobre cuáles serán los impactos de la genética aplicada al rendimiento deportivo y en la sociedad. Los resultados de esta investigación permiten concluir que la evolución es inherente al hombre, pero, cuando se trata de la alteración genómica, se hace imperiosa la reflexión de los impactos del perfeccionamiento genético de forma a garantizar iguales libertades fundamentales en el contexto del Estado Democrático de Derecho. Con este abordaje, se demuestra que la bioética es el eje del diálogo y debate multidisciplinar que el tema involucra para la construcción de los nuevos caminos de la ingeniería genética humana.

Palabras clave: dopaje; ingeniería genética; bioética; derecho; democracia

\section{Gene Therapy and Genetic Doping: Bioethical and Biolegal Dialogues}

Abstract: The application of genetic engineering in sports awakens the debate with the creation of genetically modified athletes, from genetic doping. In this sense, these studies seek to address the genetic improvement in sport, presenting its main bioethical and bio-legal questions. Therefore, authors in Biolaw, Bioethics, Philosophy and Genetics were investigated, given the interdisciplinary nature that the subject demands. Thus, the distinction between treatment and improvement was presented, with gene therapy and genetic doping, and, immediately, focused on the bioethical and legal issues that the object of the research involves, so that, in the end, the reader can reflect on the impacts of genetics applied to sports performance and society. The results of this research allow us to conclude that evolution is inherent to man, but when it comes to genomic alteration, it is imperative to reflect on the impacts of genetic improvement in order to guarantee equal fundamental freedoms in the context of the Democratic Rule of Law. With this approach, it is demonstrated that bioethics is the axis of the multidisciplinary dialogue and debate that the topic involves for the construction of the new paths of human genetic engineering.

Key words: doping; genetic engineering; bioethics; law; democracy 


\section{Introdução}

$\mathrm{O}$ advento da engenharia genética mudou o paradigma da concepção do humano com as possibilidades obtidas a partir do mapeamento genético na identificação de genes defeituosos causadores de doenças, da manipulação genética, da terapia gênica com a correção de enfermidades genéticas, do diagnóstico pré-implantatório, na possibilidade de introduzir no útero um embrião sadio com a reprodução assistida e a clonagem.

Junto a estes avanços inimagináveis, a ciência médica, por meio da Genética, trouxe novas formas de cuidar da saúde, não somente no sentido do tratamento, mas com a prevenção, por meio da medicina preditiva, oriunda de testes genéticos. Assim, a engenharia genética tornou-se instrumento capaz de melhorar consideravelmente a qualidade de vida, trazendo esperança de cura para doenças antes mesmo de se manifestarem. Mas, por outro lado, descortina "o brincar de Deus", dando a possibilidade de criar, se assim pode-se dizer, e, se é possível, o ser humano perfeito, produzido geneticamente.

Neste sentido, a engenharia genética de melhoria e o termo melhoramento genético tornam-se sinônimos, pois no "melhoramento genético a meta da intervenção não é tratar ou prevenir uma doença, mas conseguir outro resultado, como o incremento de estatura, inteligência, resistência a doenças ou uma determinada habilidade musical" (Drumond, 2011), além de aumentar o desempenho esportivo, representado no doping genético, cuja técnica provém da terapia gênica.

A terapia gênica é mais um dos desdobramentos da engenharia genética, com o objetivo de curar ou prevenir doenças ligadas à genética ou não, a partir da modificação, substituição ou acréscimo de determinado gene para o tratamento (Pierce, 2011).

A terapia gênica pode ser aplicada nas células de linhagem reprodutiva ou germinativa, como espermatozóides, ovócitos e as células do embrião ainda nas primeiras fases de formação, e nas células somáticas, que são as demais células do organismo (Nys, 2002).
A terapia somática envolve o uso de vírus, o qual é inoculado nas células do paciente para inserir o material genético saudável no gene defeituoso, com a finalidade de reprodução e transferência, resultando na correção do gene (Sá e Naves, 2011).

Já a terapia gênica germinal pode ser realizada nos gametas, espermatozóides ou óvulos, sendo somente possível por meio da reprodução assistida, realizada na fase pré-implantatória, no zigoto ou no embrião ainda em início de formação (pré-embrião), para corrigir a anomalia genética presente, alterando o genoma em definitivo (Diniz, 2006).

Questão que envolve bastante polêmica acerca da terapia gênica nas células germinativas é a alteração do genoma do futuro ser com fins de melhoramentos, como características físicas: altura, cor da pele e olhos, capacidades físicas, como força e rapidez, e intelectuais, tornando-se em "superbebês", que transmitirão estas características às suas descendências (Pérez, 2012).

Dessa forma, visualiza-se evidente correlação entre a terapia gênica e o doping genético, na medida em que aquela tem o fim de tratamento e este o de melhoramento no meio esportivo.

Nesse contexto, objetiva este artigo trazer reflexões da aplicação da engenharia genética na terapia gênica e no doping genético, sob o ponto de vista da bioética e do biodireito.

Para tanto, no 2 se abordará a discussão entre o que é tratamento e o que é melhoramento, apresentando seus conceitos e a crítica que existe aos mesmos, questionando-se se é possível haver uma diferenciação entre ambos.

No capítulo 3, debatem-se os contornos bioéticos e jurídicos da terapia gênica e o doping genético, bem como os benefícios e malefícios que podem acarretar para a humanidade, trazendo o embate entre os grupos trans-humanistas e bio-conservadores, junto a uma abordagem interdisciplinar.

Ao final, a pesquisa traz como resultado não trazer respostas ao leitor, muito mais questionamentos e reflexões das implicações da terapia gênica e do doping genético na sociedade, de forma a propiciar o diálogo e o debate democrático dos caminhos que a engenharia genética impactará em nossas vidas. 


\section{Tratamento X Melhoramento - terapia gênica e doping genético}

Como fora apontado na introdução deste artigo, o doping genético ocorre por meio do mesmo procedimento da terapia gênica. Daí surge uma questão controvertida: como saber se o uso será para o tratamento, visando à cura de uma doença, objetivo da terapia gênica; ou um melhoramento com o fim de aperfeiçoar o desempenho atlético, ainda na remota chance de não causar nenhum dano ao atleta?

Antes de se adentrar na resposta dessa pergunta, cabe acrescentar que com o objetivo de alcançar um resultado que não é tecnicamente produzido de forma natural pelo competidor, o doping genético violaria o espírito esportivo e a prática do jogo limpo, sendo vedado pela WADA (World Anti-DopingAgency).

Segundo Vasconcelos:

O recurso à manipulação genética com o fim de proporcionar desempenhos esportivos superiores, ainda que não seja comprovadamente nocivo à saúde do atleta, contraria fatalmente o espírito esportivo, preenchendo critério para a inserção na lista de interdições. Trata o espírito esportivo de valor intrínseco ao esporte, que exorta à prática do jogo limpo. (2012, p. 37).

Mas se o atleta sofre uma lesão, a tal ponto que somente uma técnica como a terapia gênica pudesse restabelecer a funcionalidade "normal" do órgão ou membro afetado? Ainda assim estaria se falando em melhoramento, num possível caso de doping genético e violando o espírito esportivo?

Segundo Coelho:

Especificamente para o esporte, a terapia gênica oferece um caminho promissor como terapia na recuperação de tecidos de baixa capacidade regenerativa, tais como tendões, cartilagens e músculos esqueléticos, facilitando a recuperação de rompimentos de ligamentos cruzados, meniscos, lesões em cartilagens e calcificação óssea tardia pela inserção de fatores de crescimento para estimular a cicatrização; nesses casos, a grande dificuldade é estabelecer a linha divisória entre a terapia e o aprimoramento genético. (2012, p. 171).

Portanto, para tentar trazer esta discussão com mais clareza torna-se necessário distinguir tratamento ou terapia e melhoramento ou enhancement.
Vários autores (Drummond, 2011; Coelho, 2012; Pessini, 2006; Brasil, 2011; Bomtempo, 2015 y Pérez, 2012) apontam suas definições entre estes dois termos. A princípio, entendem que a terapia objetiva o restabelecimento do estado normal de saúde, que mesmo adotando o conceito dado pela Organização Mundial de Saúde (OMS) (Organização Mundial de Saúde) resta bastante subjetivo, como do ponto de vista físico, psíquico e social. Já o melhoramento ou aperfeiçoamento seria tudo aquilo que causa alteração além do que é natural ao próprio indivíduo, vai além da cura de uma doença.

Drumond, por exemplo, entende que a aplicação da terapia gênica no esporte se torna um desafio paradigmático. Para ele, a terapia visa ao tratamento com a restituição da saúde e do restabelecimento de atividade adequadas do indivíduo, enquanto que o aperfeiçoamento seria o uso da biotecnologia de forma direta para aumentar as capacidades naturais e habilidades, sejam anatômicas ou psíquicas (Drumond, 2011)

Feita esta diferenciação, entra-se no ponto da discussão, mas qual o liame entre a terapia e o melhoramento? Surgem alguns questionamentos, como se a terapia é o restabelecimento da saúde normal, para quem é considerado o padrão de normalidade?

Pessini (2006) elucida a partir de diversos argumentos. O primeiro seria que terapia e melhoramento se entrecruzam, ou seja, são "duas faces da mesma moeda", porque todas as terapias que alcançam seu êxito geram aperfeiçoamento. O segundo argumento seria que os dois termos estão ligados à ideia de saúde e ao padrão de normalidade, que é um conceito que muda com o tempo e cultura. $\mathrm{O}$ terceiro argumento seria a diferença entre saudável e doente, que não são características evidentes, na medida em que uma pessoa faz uso de terapia se tem uma deficiência de ordem genética, mas seria aperfeiçoamento se apresenta os mesmos traços da deficiência, mas não é diagnosticada. Cita o autor o exemplo do anão genético que seria caso de tratamento e de uma pessoa que é anã que não apresenta deficiência genética, e que seria o caso de melhoramento (Pessini, 2006).

Há quem entenda ainda, como Juengst (2004) citado por Drumond (2011) que a distinção entre tratamento e melhoramento se apresenta dentro 
de uma delimitação no âmbito da prática médica profissional. Isto porque tratamento seria qualquer intervenção que médico e paciente considerassem apropriadas, e melhoramento seriam práticas dissociadas do alcance profissional médico. Assim, se um médico receitasse um complemento nutricional para aumentar a massa muscular de seu paciente seria uma forma de tratamento, e, já o indivíduo que levanta peso em uma academia com o acompanhamento de um personal trainer, que fizesse o uso do mesmo complemento nutricional, estaria diante de uma forma de melhoramento.

Outro ponto que enriquece o debate é que toda terapia de certa forma traz um melhoramento, ao curar um doente, houve um melhoramento, na medida em que aquele tratamento está fortalecendo o organismo (Brasil, 2011, p. 99).

Exemplifica (2011) com o medicamento chamado metilfenidato, usado para o tratamento de crianças com déficit de atenção e hiperatividade (TDAH), cuja finalidade para tratar este transtorno é a terapêutica. Entretanto, se o mencionado medicamento for consumido por este mesmo paciente com o objetivo de fazer uma prova de vestibular será o caso de melhoramento, isto é, ao mesmo tempo em que este remédio trata o déficit de atenção, traz uma vantagem ou um melhoramento nos estudos, podendo conferir um melhor resultado, como em um vestibular.

No que tange ao tema destes estudos, têm-se os casos notórios de Messi, jogador de futebol da Argentina e Tiger Woods, golfista norte-americano. $\mathrm{O}$ primeiro tomou hormônio de crescimento na adolescência por prescrição médica e o segundo realizou cirurgia nos olhos por problemas de visão (Pérez, 2012) Ambos fizeram uso de tratamentos, mas que tiveram consequências de melhoramento, já que a alta estatura e a força muscular de Messi proporcionam-lhe maior vantagem diante de uma disputa no domínio da bola e a visão apurada de Tiger Woods lhe confere uma tacada mais certeira.

Se partir deste pressuposto, não se pode entender que a terapia gênica seja proibida no âmbito esportivo, desde que usada para a regeneração de tendões, cartilagens e mesmo ossos, ou seja, com a finalidade terapêutica. No entanto, se usada somente para fins de melhoramento ou aperfeiçoamento, deve ser proibida, assim como determina a WADA, na roupagem de doping genético. Até então Messi e Tiger Woods competem tranquilamente em seus respectivos campeonatos, e, por tais usos, nunca foram penalizados por isto.

Questionam Artioli, Hirata e Lancha Júnior que: [...] Segundo a definição da WADA, o uso não terapêutico de técnicas de transferência de genes que possam melhorar o desempenho esportivo é considerado doping e, portanto, proibido. Tal definição, apesar de clara, não contempla diversas possibilidades, como também não menciona as conseqüências do direito dos atletas de usar a terapia gênica. Por exemplo, uma pessoa que sofra de alguma distrofia muscular ou anemia grave poderia se tornar atleta após o uso terapêutico da transferência de genes como IGF-1, folistatina ou eritropoetina? Ou então, um atleta que necessite de terapia gênica e que em decorrência do tratamento adquira alguma vantagem competitiva, poderia continuar competindo? Pela definição poderia, mas tal permissão esbarra nas questões éticas e morais que dão toda a base para a proibição do doping. (2007, p. 352).

Uma possível solução para os atletas que realmente necessitassem de fazerem o uso da terapia gênica seria tornar inativo o gene artificial após o reparo da lesão, de forma a inibir qualquer tipo de desempenho além do que o atleta obtinha. Aponta Dias em entrevista à Revista Diversa que:

Seria possível “desligar” o gene após o reparo da lesão? Segundo Rodrigo Dias, algumas experiências conduzidas em ratos permitem acreditar que sim. "Podem-se alocar esses genes artificiais numa região promotora, isto é, que precisa de uma droga específica para ser ativada. Quando essa droga é injetada no sangue, o gene se torna ativo. Do contrário, ele não se manifesta”, explicou o pesquisador. Mas o funcionamento desse processo no organismo humano ainda é objeto de mera especulação. E mesmo que se torne viável, ficaria no ar uma outra questão. Como fiscalizar se o gene está ativado ou desativado? (Rodrigues, 2012)

Até chegar esta nova fase da terapia gênica, como resolver este impasse? E, como mesmo apontado, como fiscalizar se o gene foi mesmo desativado?

Por outro lado, talvez nem mesmo chegue a se manifestar o gene artificial, em razão da "complexidade de traços que tem uma natureza multifatorial, 
quer dizer, há uma complexa interação entre os fatores genéticos e os do meio ambiente; o resultado disso é que a melhoria de um gene pode, muito provavelmente, não ter o efeito desejado" (Nys, 2002, p. 79).

Assim, os liames entre a terapia gênica e o doping genético exigem um maior debate, por meio de um discurso multidisciplinar. Não basta "a definição jurídica de conceitos como defeitos e anomalias genéticas, com o escopo de salvaguardar a pessoa humana" como defende Rezende (2009). Até porque muito se falou da insuficiência dos conceitos de tratamento e melhoramento, o que traria a ineficácia da norma diante do caso concreto.

Sendo assim, propõe-se a partir do discurso interdisciplinar proposto pela Bioética e o seu consequente desdobramento jurídico imposto pelo Biodireito de se enfrentar as questões éticas e jurídicas trazidas pela terapia gênica e o doping genético, como se busca discutir adiante.

\section{A Bioética e o Biodireito: uma discussão multidisciplinar para a terapia gênica e o doping genético}

A terapia gênica e a possibilidade do doping genético desenvolveram-se proeminentemente a partir do Projeto Genoma Humano, já que este foi “o primeiro passo no caminho de nossa alfabetização - todavia, o aprendizado deve eleger o melhor método adequado para que se conheça o animal humano, sob pena de o mesmo desaparecer na era pós-genômica" (Gomes e Sordi, 2001, p. 195)

Mas, qual seria o melhor método adequado? Em qual contexto, diante de quais situações? Daí a importância de se trabalhar os aspectos éticos e jurídicos que envolvem tais questões. Isto porque o acaso ou o devir, no âmbito da genética, a loteria genética, está se tornando em desuso, haja vista a possibilidade da manipulação genética, principalmente com a terapia gênica, vislumbrando a cura de doenças provenientes de genes defeituosos, e do doping genético com a adição de genes responsáveis por conferir habilidades atléticas. "Trata-se de desmontar a loteria da hereditariedade e de suas injustiças distribuídas ao acaso" (Pessini, 2012).

Sendo assim, em recurso à engenharia genética, o homem passa a ser re-construtor de sua própria existência, estando diante de questionamentos éticos perante os limites de sua (auto)intervenção, como alerta Jonas:

[...] O homo faber aplica sua arte sobre si mesmo e se habilita a re-fabricar inventivamente o inventor e confeccionar de todo o resto. Essa culminação de seus poderes, que pode muito bem significar a subjugação do homem, esse mais recente emprego da arte sobre a natureza desafia o último esforço do pensamento ético, que antes nunca precisou visualizar alternativas de escolha para o que se considerava serem as características definitivas da constituição humana. (2006, p. 57).

Neste contexto, surge a discussão dos caminhos que a engenharia genética poderia levar, trazendo à tona a eugenia, com o risco de bebês projetados, caso seja desvirtuada a finalidade da terapia gênica (Pessini, 2006). Ademais, fatos outros poderiam ocorrer com a inserção de genes de animais não humanos em pessoas, criando criaturas distintas do conceito de humano (Pérez, 2012).

Desta forma, tais usos podem levar a uma série de complicações, como gerar desigualdade entre os seres humanos não melhorados e os melhorados, obtendo acesso somente aqueles com melhores condições financeiras, devido ao alto custo da técnica (Rodotá, 2010).

Questiona-se ainda a possibilidade da perda da variação genética humana ao longo do tempo com o melhoramento genético, pois, se a propensão é da maioria querer as melhores características e habilidades, poderia acarretar a depressão endogâmica ou erosão genética (Malajovich, 2004).

Em contrapartida, discute-se até que ponto um determinado gene responsável por uma característica específica teria a sua expressão alcançada a partir do melhoramento genético. Ora, o genótipo manipulado não é o único responsável para que o indivíduo apresente o fenótipo esperado, como já pode se comprovar com os resultados do Projeto Genoma Humano.

Assim, "acreditar que a solução dos problemas da humanidade possa estar na melhoria dos seus genes significa conferir à genética um poder que ela 
não tem, apesar de muitos acreditarem (ou temerem) que ela tenha" (Matte, 2004, pp. 1074-1075).

Portanto, a interação do genótipo do indivíduo com o ambiente é que vai determinar certa característica, não sendo possível prever a sua manifestação. Ademais, o próprio DNA pode sofrer modificação ou ser influenciado pelo ambiente, $o$ que a inserção ou modificação externa por si só não são suficientes para a expressão do gene manipulado. Fala-se da epigenética:

A estrutura e a organização do gene são ainda influenciadas por mecanismos de controle que fazem com que o DNA seja modificado ou influenciado sem alterar a sequência de DNA herdada e que podem ser herdados de modo estável. Esta forma de regulação, um aspecto importante de interação com o genoma foi chamada de epigenética. [...] (Westman, 2006, p. 48).

Ou seja, podem ocorrer modificações genéticas, sem que a sequência do DNA seja alterada, a nível intramolecular, segundo estudos afetos à epigenética.

Noutro ponto, existe também, como fora trabalhado no item anterior, qual o liame do caso que merece tratamento e do outro que se trata de melhoramento, já que a técnica de terapia gênica é uma só. Se a sua finalidade é o que distingue, é uma questão de saúde ou de eugenia?

Ainda que a terapia gênica seja ética e juridicamente defensável, como será visto adiante, todavia, questionam-se quais seriam os limites da engenharia genética, principalmente no que tange ao melhoramento genético, como o doping genético, na medida em que a ciência deve ajudar a promover a qualidade de vida do homem, a buscar o seu aperfeiçoamento.

Visualiza-se, desta maneira, uma nova forma de intervenção corporal, a partir do melhoramento genético, criando-se novos contornos diante da autonomia do corpo.

Apesar de restrições éticas e jurídicas que envolvem o melhoramento genético a ser discutido ao longo deste artigo, questiona-se que esta nova forma de melhoria deva ser objeto de escolha de cada um, diante de várias outras intervenções de melhoria corporais permitidas e cotidianamente utilizadas, na perspectiva de um corpo em constante construção (Stancioli, 2011).
Porém, cai-se numa retórica, pois, a liberdade de buscar o melhoramento ficará submissa à vontade de outrem. Isto é, ainda que um indivíduo por motivos próprios não deseje determinado tipo de melhoramento, este se verá tolhido a fazê-lo, sob pena de ficar em situação de desvantagem perante o outro que assim o fez (Matte, 2004).

Não restam dúvidas dos impactos trazidos com o PGH e sua significação na conformação de um novo conceito de identidade e pessoa, mas que requer mais debates e discussões acerca destes novos avanços biotecnológicos com a engenharia genética (Coelho, 2012). Nesta esteira, aparecem alguns grupos a favor e contra o melhoramento humano, os quais sob o mesmo fundamento, a vida e a dignidade humana, mas em posições contrárias, defendem seus pontos de vista.

Busca-se então no capítulo adiante trazer os argumentos dos trans-humanistas e dos bio-conservadores.

\section{O debate entre trans-humanistas e bio-conservadores}

O trans-humanismo ou pós-humanismo, como descreve Bostrom (2005a), é um movimento que tomou força nas últimas décadas, tendo como origem o humanismo secular e o Iluminismo. Para os seus adeptos a "natureza humana é aprimorável através do uso da ciência aplicada e de outros métodos racionais, que podem tornar possível o aumento da longevidade da vida humana, estender as nossas capacidades físicas e intelectuais e nos dar um maior controle" (2005) das funções mentais. São cativos a qualquer forma de aperfeiçoamento, seja por qualquer tipo de tecnologia, inclusive a engenharia genética, bem como inteligência artificial, ou seja, na conjugação homem e máquina.

O objetivo dos trans-humanistas, como defende Bostrom (2005b), é a disponibilização dos recursos tecnológicos que visam ao melhoramento estarem ao acesso de todos que desejam utilizá-los, sem causar danos à sociedade e sem a coerção de potenciais riscos.

Tem-se como exemplo de grupo de trans-humanistas os extropianos (Extropy, 2005). Entendem que a natureza humana não é estática e que 
os avanços tecnológicos devem ser usados a favor do homem e em si mesmo, o que não acarretaria a extinção da espécie, mas sim a sua evolução no pós-humano, o que não é natural ao homem. São adeptos da clonagem, da robótica com a implantação de chips para se conectar a computadores, do melhoramento genético e mesmo na fusão homem e máquina (Mello e Bomtempo, 2013) e, porque não, do doping genético.

Os trans-humanistas defendem a liberdade de escolha do uso da tecnologia para melhoramento do indivíduo em si mesmo, como uma "liberdade morfológica" (Bostrom, 2005a, p. 2) e, inclusive dos pais optarem por quais formas de tecnologias querem que seja utilizada em seus filhos, como "liberdade reprodutiva" (p. 2).

Desta forma, entendem que não haveria uma violação da dignidade humana, mas sim a reconstrução de uma dignidade pós-humana, pois o DNA não representa o homem, mas a sua biografia. "A natureza humana, nesse sentido mais amplo, é dinâmica, parcialmente feita pelo homem, e aprimorável. Nossos atuais fenótipos estendidos (e as vidas que levamos) são marcadamente diferentes daquelas dos nossos ancestrais caçadores-coletores" (2005a, p. 13).

Ainda que haja possíveis riscos, que devem ser evitados, os pós-humanistas entendem que se os benefícios forem maiores, a tecnologia de melhoramento deve ser aplicada. Nesse futuro estado pós-humano seria possível uma longevidade com saúde e qualidade de vida indefinida, características superdesenvolvidas e a criação de novas habilidades, como controlar os próprios sentimentos (Bostrom, 2005a).

Cabe ressaltar que o ideal trans-humanista não é meramente egoístico, o melhoramento advindo com a tecnologia, como a engenharia genética, deve conferir um benefício à sociedade como um todo, sob a forma de uma política pública. Ainda que traga externalidades positivas individuais, mas confira um progresso à sociedade como um todo, deve ser aplicado. Caso contrário, na hipótese de somente trazer vantagens pessoais, poder-se-ia tributar ou onerar aquele que o usufrui, como sugere Bostrom (2005a).
Em posição contrária aos trans-humanistas, existem os bio-conservadores ${ }^{1}$. Estes são contra o uso da tecnologia para o aperfeiçoamento humano, pois sustentam que o melhoramento é desumano, na medida em que coisifica o próprio homem e viola a sua dignidade (Mello e Bomtempo, 2013).

Isto porque as tecnologias de melhoramento humano, sobretudo a engenharia genética, para os bio-conservadores, modificam a natureza humana, desvirtuando a concepção de humano.

A análise do custo e benefício destas intervenções tende a não ser aceita na visão bio-conservadora, principalmente se sob um viés religioso ou com bases seculares como argumentam os trans-humanistas. Sendo assim, devem ser implementadas ações que proíbam as tecnologias de melhoramento, sob pena de se tornar um estado pós-humano que poderá extinguir a natureza humana (Bostrom, 2005a)

"Impõe-se a questão de saber se a tecnicização da natureza humana altera a auto-compreensão ética da espécie de tal modo que não possamos mais nos compreender como seres vivos eticamente livres e moralmente iguais, orientados por normas e fundamentos" (Habermas, 2004, p. 57).

Por derradeiro, o melhoramento genético, como o doping genético e a seleção de embriões devem ser proibidos do ponto de vista dos bio-conservadores, sob pena gerar uma possível discriminação genética, onde terão mais valor os indivíduos transgênicos ou melhorados diante dos não melhorados, levando ao cenário do filme

1 Grupo de bio-conservadores bastante radicais são os amish, "componentes de comunidades religiosas ortodoxas quem voluntariamente, abdicaram de todo o progresso tecnológico, permanecendo estacionados no tempo e fechados em suas vilas, desprovidos de comunicação, medicamentos e inúmeros outros 'avanços', como, em alguns casos, a energia elétrica." (Brasil, 2011, p. 102). 
Gattaca - Experiência Genética ${ }^{2}$. De acordo com Corrêa e Guilam:

[...] A identificação de genes supostamente ligados a traços cognitivos, físicos e de comportamento, adequados a ideais socialmente dominantes de competitividade, beleza, ou perfeição poderia vir a comandar a seleção de embriões. Os pais poderiam justificar tal projeto em nome de uma suposta hierarquização das pessoas, segundo atributos físicos e mentais e em função da valorização desses atributos. Enfocada dessa forma, as tecnologias de determinação da "normalidade" de um feto poderiam criar padrões de vida pré-natal: bebês que valem e outros cujo nascimento não tem valor, o que reedita o debate sobre a eugenia. (2006, p. 2142)

Portanto, os bioconservadores legitimam somente a terapia gênica, em seu estrito termo, somente para fins terapêuticos, como último recurso para tratamento e, ainda assim, com estrita segurança no procedimento (Rezende, 2009, p. 54).

Diante das divergências apontadas, não se adota o posicionamento de nenhum dos dois grupos. A evolução do homem é um processo que precisa manter o seu curso, porém, este processo implica reflexão, diálogo, discursividade e, sobretudo, responsabilidade, de forma a não violar a dignidade, e, por consequência, a essência do que é humano.

Neste contexto, torna-se importante inserir a temática destes estudos na Bioética e no Biodireito como forma de construir eticamente e juridicamente um discurso dialógico e com responsabilidade; tratando-se, assim, por meio de um debate reflexivo, as implicações do uso do melhoramento humano, como o doping genético e mesmo a terapia

\footnotetext{
2 Gattaca se passa num suposto tempo futuro não tão distante, onde mostra uma sociedade em que o Estado tem controle sobre a visão social da qualidade genética. A partir da manipulação genética criaram-se novas espécies de castas, preconceitos e divisões sociais, aparentemente legitimadas pela ciência. Aos pais que desejam ter filhos é dada a oportunidade de escolher e manipular a interação entre seus gametas para gerarem filhos com a melhor combinação de qualidade genética possível. Esse procedimento acaba criando uma distinção de quem está mais apto para fazer o que na sociedade e, como resultado final, gera uma tarja a ser carregada pelo resto de suas vidas: válido, quem é fruto dessa combinação genética planejada, ou não-válido, quem não foi melhorado geneticamente, estando propenso a doenças e deficiências, mesmo que mínimas (Wikipedia, 2018)
}

gênica, objetivando assegurar iguais liberdades fundamentais e a preservação da dignidade.

\section{A Bioética}

A ética busca uma verdade universal do que é válido, do que é correto. Diante dos avanços biotecnológicos torna-se necessária uma reflexão ética destes avanços, em especial o melhoramento genético, como o doping genético. Assim, contrapõem-se dois lados desta ética universalista: "a defesa exagerada do Estado, por um lado, e do liberalismo radical, por outro" (Costell, 2002 p. 287)

$\mathrm{O}$ agir ético deve empreender-se pela boa conduta, o que é correto e aceito pela sociedade, do ponto de vista social e psicológico, na intenção da ação. No entanto, o que é ético, às vezes não é aceito do ponto de vista da moral, pois esta envolve o contexto histórico, a cultura, fatores sociais e outras circunstâncias.

No contexto da ética contemporânea, a ética deve ser democrática, dado os díspares valores que abarcam a sociedade plural atual. Assim, deve-se buscar uma abordagem multidisciplinar de forma a dar a resposta mais correta naquele determinado caso, levando-se em consideração à dinâmica que envolve as relações sociais, sobretudo, no contexto da vida e dignidade humana quando se trata das ciências biomédicas (Fortes, 1998).

Por conseguinte, em enfrentamento a estas questões que envolvem o uso da biotecnologia, urge-se por uma reflexão multidisciplinar, papel conferido à Bioética ${ }^{3}$.

"A bioética é personalista, por analisar o homem como pessoa ou como um "eu", dando valor fundamental à vida e às dignidades humanas, não admitindo qualquer intervenção no corpo humano que não redunde no bem da pessoa" (Diniz, 2006, p. 7-8).

Este aspecto personalista da bioética é baseado no princípio da beneficência, o qual consiste

\footnotetext{
3 "A palavra Bioética tem origem etimológica em duas palavras gregas: Bios e Éthos. Bios significa vida e Éthos significa ética. A ética é erroneamente confundida com a moral, devido ao fato de ambas se originarem de éthos, termo grego, que, "quando escrito com "e" breve, significa "hábito", enquanto que com "e" longa, significa "propriedade de caráter." (Hryniewicz e Sauwen, 2008, p. 3)
} 
que qualquer intervenção médica deve promover o bem-estar psicofísico do paciente (Diniz, 2006).

Apesar de não haver um consenso de um conceito preciso de bioética que esclareça o que exatamente ela seja (Tavares et al., 2009), adota-se nestes estudos que a Bioética é a ética das ciências no seu sentido global, por buscar respostas a partir de um discurso conjunto de todas as áreas científicas que podem ser envolvidas com a criação de novas tecnologias. Por exemplo, discute-se neste trabalho o doping genético, mas não há como trazer um panorama completo do tema se não abordar a antropologia, o esporte, junto à educação física e à medicina desportiva, a filosofia, a medicina genética e o direito, ou seja, isto é um estudo bioético, de forma a tentar trazer reflexões mais abrangentes possíveis, dentro de um debate multidisciplinar.

Marco importante do histórico da Bioética foi o desenvolvimento do paradigma principialista da Bioética, proposto por Tom Beuchamp e James Childress, com os quatro princípios bioéticos: beneficência, não maleficência, justiça e autonomia. Noticiam Pessini e Barchifontaine:

O paradigma principialista está entre os modelos de análise bioética mais divulgados e tem como protagonistas Tom Beuchamp e James Childress, autores da obra clássica Principlesofbiomedicalethics (em 1994 já haviam quatro edições). Esses autores propõem quatro princípios orientadores da ação: beneficência, não maleficência, justiça e autonomia [...]. (2012, p. 46)

Os princípios bioéticos não possuem hierarquia. Diante de eventual conflito, será o caso concreto que indicará qual é o mais adequado. "Esse modelo tem ampla aplicação na prática clínica, em todos os âmbitos em que a bioética se desenvolveu, com resultados bastante positivos em relação ao respeito pela dignidade da pessoa" (2012, p. 46).

Ressalta-se que os princípios bioéticos não têm imperatividade, isto é, não possuem força de lei, não são coercitivos, são abertos e possuem conteúdo valorativo, diante do que seja o bom ou o melhor em cada situação, cabendo ponderação ou ordem de preferência, já que um não necessariamente afasta o outro (Naves, 2010).

No que tange à aplicação das tecnologias de melhoramento no esporte a partir dos princípios bioéticos, com base em Drumond (2011): quais seriam os benefícios do doping genético, bem como quais aperfeiçoamentos serão realizados (beneficência)? Seriam tais melhoramentos apropriados, preservando a integridade psicofísica do atleta, e quais riscos existem (não-maleficência)? Essa técnica estaria disponível a todos os atletas e à sociedade (justiça)? O atleta que fizer uso do doping genético tem ciência de todos os riscos da técnica estará agindo em razão de qual motivo (autonomia)?

Nesse contexto, tais reflexões devem ser trazidas para o debate junto à sociedade, pois todos de forma direta ou indireta sofrerão com os impactos do doping genético. Como alerta Drumond (2011), quais serão os benefícios do doping genético? A adição de determinado gene responsável por conferir certas habilidades, como força e resistência realmente trarão um melhor resultado ao atleta, já que a expressão de um gene também se relaciona a fatores ambientais, como se abordou? Quais os reais riscos do doping genético? Quais tipos de reações ou doenças que podem ocasionar no organismo? $\mathrm{O}$ método será disponibilizado para todos os atletas? E o restante da sociedade? Já que os atletas também são pessoas comuns, que tipo de distorções que o doping genético poderia causar nas relações sociais? Haveria autonomia para o atleta que não quisesse fazer uso do doping genético diante dos outros competidores fazerem uso deste tipo de dopagem? Não se sentiria coagido, sob pena de perder a prova e por consequência, o apoio de patrocinadores?

Se mesmo a terapia gênica que ainda está em fase experimental e por ser uma técnica com custo elevado está longe do alcance de grande parte da população, seria ético haver recursos para um atleta de elite e não ter recursos para uma criança com leucemia? Como aponta Nys:

Um segundo problema de justiça é colocado na distribuição de recursos de amparo à saúde, problema que em breve afetará a terapia gênica, que é muito cara devido a seu caráter de inovação. Se o tratamento é eficaz, ele será barateado e estendido gradualmente à medida que a técnica avance; não obstante, é um tratamento que será sempre caro, pois requer muito estudo e apoio de laboratório. Os critérios para fixar prioridades em amparo à saúde devem ser estudados, discutidos e estabelecidos globalmente. (2002, p. 72) 
Ademais, no que diz respeito à terapia gênica, seria ético aplicá-la em células germinativas? Quais tipos de questionamentos devem ser feitos diante da possibilidade de interferir no patrimônio genético? Haveria violação da dignidade humana? Observa Nys que:

[...] não há provas irrefutáveis que assegurem que a terapia reprodutiva afete a priori a dignidade humana e a justiça. A única razão sólida hoje em dia para se opuser à terapia reprodutiva é a incerteza científica, que nos impede de avaliar riscos e benefícios; enquanto essa situação perdure, seria irresponsável e deve ser proibida qualquer intenção de aplicar terapia gênica reprodutiva em seres humanos. Tão logo a situação se esclareça de um ponto de vista científico, terá que ser objeto de uma reavaliação ética. (2002, p. 78)

Diante destas indagações, percebe-se a importância do papel da bioética como promotora da reflexão dos avanços da biotecnologia, a partir de um discurso multidisciplinar.

Todavia, como exposto, a Bioética está no campo da Ética, da deontologia, o que não lhe confere coercibilidade, caráter de imposição como a lei, carecendo de proteção jurídica a ser suprida com o novo ramo do Direito, o Biodireito, o qual se propõe tratar a seguir.

\section{O Biodireito}

O Biodireito surgiu a partir da necessidade de se tutelar juridicamente questões que envolvam a Bioética, que, por meio da coerção, todos obedecessem a seus regramentos, seja através de dispositivos legais ou princípios.

Anunciam Sá e Naves (2004) o surgimento do Biodireito a partir da Bioética, não no sentido somente da proteção do direito à vida enquanto incolumidade psicofísica, mas da tutela de todos os bens sem os quais a vida não pode se desenvolver com dignidade.

Distinto é o Biodireito da Bioética, pois aquele faz parte do Direito e esta da Filosofia, uma vez que traz discussões abertas, com premissas provisórias e precárias, e respostas de cunho filosófico (Naves e Sá, 2002). "Já o Biodireito é disciplina jurídica, nascida da necessidade de se regular normativamente e julgar as condutas e procedimentos interventivos na vida humana e de outros seres vivos" (Naves, 2010, p. 126).

Assim, o Direito não pode "vendar os olhos" para os desafios trazidos pela biotecnologia, conferindo ao Biodireito o papel de garantir direitos fundamentais a serem observados por todos. "Os avanços da medicina que prometem trazer grandes benefícios à humanidade, e o consequente aumento do interesse humano nesse campo de pesquisa, fez surgir à necessidade de tutelar alguns temas da Bioética através de um novo ramo jurídico: o Biodireito" (Tavares et al., 2009, p. 28).

O Biodireito, como mais um novo ramo jurídico, revela a exigência cada vez maior do Direito se expandir em várias disciplinas, condizente com a provocação de cada caso concreto a ser delimitado, a fim de se buscar a resposta mais adequada. Neste sentido, se enquadra como microssistema, que "se verifica em razão da instalação de nova ordem protetiva sobre determinado assunto, com princípios próprios, doutrina e jurisprudências próprias, autônomos ao Direito Comum" (Sá e Naves, 2011, p. 16) Além do Biodireito, tem-se como exemplo o microssistema do Consumidor, do Idoso, da Criança e do Adolescente, entre outros.

Dessa forma, o microssistema do Biodireito, nova área do Direito, é criado para buscar soluções jurídicas aos questionamentos advindos com os avanços biomédicos, envolvendo temas bioéticos.

Desta forma, na medida em que os regramentos legais não sejam suficientes para solucionar os problemas enfrentados na Bioética, torna-se essencial a aplicação de princípios ${ }^{4}$ jurídicos. Isto porque o Biodireito não pode ser entendido somente pela lei, já que a evolução da biotecnologia avança a passos largos, o que envolve a busca de respostas jurídicas no mesmo compasso, sob pena de violar direitos fundamentais. Porém, isto não quer dizer que leis devam ser criadas, pois da elaboração até a entrada em vigor da lei há intensos debates de ordem moral, principalmente

\footnotetext{
4 "Os princípios são normas com um grau de abstração mais elevado e, de outra maneira, as regras possuem uma abstração relativamente reduzida. Os primeiros são vagos e indeterminados, enquanto as regras são geralmente suscetíveis de aplicação direta." (Semião 2012, p. 97).
} 
religiosos, sendo necessário recorrer à principiologia jurídica para trazer a resposta mais adequada naquele momento diante do caso concreto ${ }^{5}$ (Sá e Naves, 2011).

Diferenciações feitas, alguns autores chegam a apontar quais seriam os princípios do Biodireito, outros nem mencionam. Santos (2001) e Diniz (2006) não chegam a apontá-los, fundamentam o Biodireito com base na dignidade da pessoa humana.

Barboza (2003) afirma que os princípios biojurídicos são constituídos por princípios constitucionais, como a dignidade, a vida e a liberdade.

Já Sá e Naves (Sá e Naves, 2011) ousam apontar quais seriam exatamente os princípios do Biodireito: precaução, responsabilidade, autonomia privada e dignidade.

O princípio da precaução relaciona-se ao princípio bioético da não maleficência, pois implica em adotar medidas que não causem danos graves ou irreversíveis.

No que tange ao princípio da responsabilidade, este se relaciona ao princípio bioético da justiça e implica que a pessoa tem o dever jurídico de "satisfazer as obrigações convencionadas ou suportar as sanções legais impostas por seu descumprimento" (Sá e Naves, 2011, p.38). Ou seja, o médico ou cientista é responsável por seus atos, sob pena de responder civil e criminalmente.

Já o princípio da autonomia privada relaciona-se ao princípio bioético da autonomia.

A autonomia privada infere na autodeterminação do indivíduo, no exercício de sua liberdade, com capacidade e discernimento, o que na perspectiva biojurídica e bioética trabalha-se com o consentimento livre e esclarecido do paciente.

Por fim, a dignidade humana é o princípio do Biodireito relacionado à beneficência, já que se pode afirmar que é o conjunto de todos os outros princípios, de forma a conferir o melhor para o indivíduo, em respeito a sua integridade psicofísica.

\footnotetext{
5 São exemplos de decisões judiciais no âmbito do Biodireito que trouxeram grande repercussão na sociedade a Arguição de Descumprimento de Preceito Fundamental (ADPF) n ${ }^{\circ} .54$, acerca da interrupção da gravidez na hipótese do feto ser anencéfalo, $e$ a Ação Direta de Inconstitucionalidade (ADI) n.3510, que trata da liberação de pesquisas com células-tronco embrionárias.
}

Deve-se atentar, entretanto, que a dignidade da pessoa humana serve de fundamento para posições contrárias, a exemplo do uso da terapia gênica: serve de fundamento na violação da dignidade das gerações futuras ou na cura de doença de origem genética de forma a garantir ao paciente saúde e dignidade.

Assim, deve-se entender como defendido por Sá e Naves (2011) que a dignidade, como princípio de Biodireito, deve ser aplicada no contexto de iguais liberdades fundamentais, de forma que a liberdade de um não prejudique a do outro.

Diante do exposto, pode-se inferir na aplicação dos princípios biojurídicos ao doping genético da seguinte forma:

a) O princípio da precaução seria aplicado na hipótese de que na medida em que não se tem o conhecimento que este método (doping genético) possa causar danos irreversíveis, este deve ser evitado, tanto na preservação da saúde do atleta quanto na proteção das gerações futuras;

b) No que tange ao princípio da responsabilidade, se a dopagem genética vir a uso, os envolvidos, como atletas, médico e equipe, são responsáveis pelos atos cometidos, podendo responder por possíveis danos nas gerações futuras ao modificar o genoma humano, além da saúde do paciente atleta;

c) Já a autonomia privada poderia ser aplicada com base em uma escolha livre e esclarecida a partir do momento em que os atletas obtivessem todas as informações dos riscos que envolvem o doping genético, devendo o profissional médico e equipe avaliarem os potenciais danos à saúde do paciente;

d) Por fim, o princípio da dignidade se faria presente para evitar a discriminação genética e eugenia, em razão de outros atletas que não possuem recursos financeiros para o uso da dopagem genética e para proteger o genoma humano das gerações futuras, sendo o doping genético coibido se aplicado este princípio. Ao mesmo tempo a dignidade, também poderia ser aplicada para se efetivar a autonomia do atleta que deseja fazer uso do melhoramento genético (Mello e Bomtempo, 2013). 
Para que se tenha uma construção própria de vida boa, todas as decisões no âmbito do Biodireito devem ser livres, desde que com responsabilidade e discernimento. Numa sociedade complexa e plural, o Direito é e deve ser dinâmico, sendo construído a partir do exercício de iguais liberdades fundamentais (2013).

Com base no que fora exposto neste capítulo, compreende-se, portanto, que as implicações da engenharia genética, sobretudo a terapia gênica e o doping genético não podem ser discutidas somente sob o olhar da Genética, ou só do Direito. Imperioso que o debate seja multidisciplinar (bioética e biodireito), de forma que as duas ciências dialoguem junto à sociedade e, diante de todos os aspectos possíveis, nós, destinatários e agentes normativos, possamos decidir os rumos do melhoramento genético, visando a respeitar individuais projetos de vida e iguais liberdades fundamentais, inseridos no Estado Democrático de Direito.

\section{Conclusões}

O doping genético, o qual é fruto da engenharia genética e procedimentado pelo mesmo processo da terapia gênica levantou questionamentos neste artigo diante do que pode ser compreendido por tratamento e melhoramento, o que permite ser atestado diante do caso concreto, refutando-se, portanto, os conceitos imprecisos que tais finalidades apresentam.

Junto a isto trouxe posições divergentes dos grupos dos trans-humanistas e dos bio-conservadores, quem defende pelo aperfeiçoamento da espécie humana como natural a sua evolução e quem apoia a terapia gênica somente para situações graves e que possa trazer chances reais de cura ao enfermo, respectivamente; concluindo-se que a evolução humana é necessária à humanidade, porém, deve ser permeada por crivos éticos e jurídicos.

Diante das divergências apontadas, não se adota o posicionamento de nenhum dos dois grupos. A evolução do homem é um processo que precisa manter o seu curso, porém, este processo implica reflexão, diálogo, discursividade e, sobretudo, responsabilidade, de forma a não violar a dignidade, e, por consequência, a essência do que é humano.

Dessa forma, elucidou-se os principais impactos e mitos que a terapia gênica e o doping genético podem acarretar, seja a nível de células somáticas e germinais, tanto do ponto de vista biomédico junto à genética, como ético e jurídico.

Mesmo a possibilidade de se concretizar consequências danosas à humanidade, como criação de bebês à la carte, eugenia e discriminação genética, com suporte em estudos genéticos, observou-se que a dopagem genética pode não ser tão efetiva como se imagina, rechaçando-se o determinismo genético. Isto porque existem diversos fatores de ordem genética que são alheios à vontade humana e interagem a nível biomolecular. Isto é, ainda que o atleta tivesse preparo físico e talento, o gene acrescido com o doping genético teria chances de não se expressar como desejado ou mesmo causar sérios danos à saúde. Ademais, ressaltou-se que junto a estas interações genéticas existe a relação entre genótipo e fenótipo, que envolve o gene e o ambiente. Resulta-se, assim, tanto variações internas como externas ao organismo.

Neste panorama, afirmou-se a importância da inserção da temática à Bioética e ao Biodireito, ao passo que o estudo exige uma análise multidisciplinar para que se possam trazer todas as variáveis que comporta o objeto do tema proposto, de forma que se desenvolva um amplo debate calcado na discursividade exigida pelo Estado Democrático de Direito. A Bioética é o eixo de construção do debate multidisciplinar do tema ora abordado, demonstrando-se que para que se possa avançar nos diálogos da construção dos limites da engenharia genética é imprescindível a participação de todas as ciências envolvidas, de forma que o discurso não caia em um vazio sem sentido.

Com base nessa informação/formação bioética é que será possível a participação de todos no debate que envolve o melhoramento genético, seja no esporte ou em outras áreas, na construção de um ideal de vida boa em que se possa abarcar individuais projetos de vida sem colocar em risco iguais liberdades fundamentais. 


\section{Referências}

Artioli, G. G., Hirata, R. D.C. e Lancha Jr., A. H. (2007) Terapia gênica, doping genético e esporte: fundamentação e implicações para o futuro. Revista Brasileira de Medicina. Disponível em: http://www.scielo.br/scielo.php?scrip$\mathrm{t}=\mathrm{sci}$ _arttext\&pid=S1517-86922007000500013\&ln$\mathrm{g}=\mathrm{en} \& \mathrm{nrm}=\mathrm{iso}$

Barboza, M. H. (2003). Princípios de Biodireito. Em: Barboza, H. H., Meirelles, J.,Barretto, V. P. (orgs.), Novos temas de biodireito e bioética (pp.49-81). Rio de Janeiro: Renovar.

Bomtempo, T. V. (2015). Melhoramento humano no esporte: o doping genético e suas implicações bioéticas e biojurídicas. Curitiba: Juruá.

Bostrom, N. (2005a). Em defesa da dignidade pós-humana. Revista Bioethics. Disponível em: http://www.ierfh. org/br.txt/ValoresTranshumanistas2005.pdf.

Bostrom, N. (2005b). Valores transhumanistas. Instituto Ética, Racionalidade e Futuro da Humanidade. Disponível em: http://www.ierfh.org/br.txt/ValoresTranshumanistas2005.pdf.

Brasil, J. (2011). Bioenhancement. En Salles, A. A. (orgs.). Bioética: velhas barreiras, novas fronteiras (pp. 99-103). Belo Horizonte, MG:Mazza Edições.

Coelho, M. M. (2012). Doping genético, o atleta superior e bioética. Revista Bioethikos. Disponível em: http:// www.saocamilo-sp.br/pdf/bioethikos/94/a6.pdf.

Corrêa, M. e Guilam, M. (2006). Discurso do risco e o aconselhamento genético pré-natal. Disponível em: http://www.scielo.br/scielo.php?script=sci_arttext\&pi$\mathrm{d}=$ S0102-311X2006001000020\&lng=en\&nrm=iso.

Costell, E. D. (2002). A reflexão ética diante do avanço da biotecnologia. Em: Romeo Casabona, C. M. (org.), Biotecnologia, direito e bioética (pp.285-289). Belo Horizonte, MG: Del Rey e Puc Minas.

Diniz, M. H. D. (2006). O estado atual do Biodireito (3 ${ }^{\mathrm{a}} \mathrm{Ed}$.). São Paulo: Saraiva.

Pérez Triviño, J. L. (2012). Deportistas tecnológicamente modificados y los desafíos al deporte. Revista Bioética de Derecho. Disponível emhttp://www.ub.edu/fildt/revista/RByD24_art-pereztrivino.htm

Drumond, J. G. F. (2011). Tecnologia e esporte: perspectivas bioéticas. Revista Bioethikos. Disponível em: http://www.saocamilo-p.br/pdf/bioethikos/89/A7.pdf.

Extropy Institute (2005). Prologue: What is the Purpose of the Principles of Extropy? Disponível em: http://www. extropy.org/About.htm.

Fortes, P. A. C. (1998). Ética e saúde: questões éticas, deontológicas e legais, tomada de decisões, autonomia e direitos do paciente, estudo de casos. São Paulo: EPU.
Gattaca. Wikipedia. Disponível em: http://pt.wikipedia. org/wiki/Gattaca.

Gomes, C. L. S. P. e Sordi, S. (2001). Aspectos atuais do projeto genoma humano. Em: Santos, M. C. C. L. Biodireito: ciência da vida, os novos desafios (pp.169-195). São Paulo, SP: Ed. Revista dos Tribunais.

Jonas, H. (2006). O princípio responsabilidade: ensaio de uma ética para a civilização tecnológica. Rio de Janeiro, RJ: Contraponto, Ed. PUC-Rio.

Habermas, J. (2004). O futuro da natureza humana: a caminho de uma eugenia liberal? São Paulo, SP: Martins Fontes.

Hryniewicz, S. e Sauwen, R. F. O. (2008). Direito "in vitro": da bioética ao biodireito. Rio de Janeiro, R. J.: Lumen Juris.

Malajovich, M. A. (2004). Biotecnologia. Rio de Janeiro, RJ: Axcel Books.

Matte, U. S. (2004). Genômica- aspectos éticos, legais e sociais. En Mir, L. (org.), Conselho De Informações sobre Biotecnologia. Genômica (pp.1067-1090). São Paulo, SP: Atheneu.

Mello, L. e Bomtempo, T. V. (2013). Melhoramento humano: de ser para coisa? Uma abordagem a partir da (des) construção da personalidade. Em: Fabriz, D C., Faro, J. P., Ulhoa, P. R., Peter Filho, J., Gomes, M.S. V. e S., H. F. (Orgs.). Direito das futuras gerações. pp.135-151. Vitória, ES: Cognorama.

Naves, B. T. O. (2010). Direitos de personalidade e dados genéticos: revisão crítico-discursiva dos direitos de personalidade à luz da 'natureza jurídica' dos dados genéticos humanos. Belo Horizonte, MG: Escola Superior Dom Helder Câmara.

Nys, H. (2002). Terapia Gênica Humana. Em: R. Casabona, C. (Org.). Biotecnologia, direito e bioética (pp. 66-80). Belo Horizonte, MG: Del Rey e Puc Minas.

Organização Mundial de Saúde. ¿Cómo define la OMS lasalud?. Disponível em: http://who.int/suggestions/faq/ es/index.html.

Pessini, L. (2006). Bioética e o desafio do transhumanismo: ideologia ou utopia, ameaça ou esperança? Revista de Bioética. Disponível em: http://revistabioetica.cfm. org.br/index.php/revista_bioetica/article/view/14.

Pessini, L.e Barchifontaine, C. P. (2012). Problemas atuais de bioetica (10 ed.). São Paulo, SP: Loyola.

Pierce, B. A. (2011). Genética: um enfoque conceitual (3 ed.). Rio de Janeiro, R. J.: Guanabara Koogan.

Rezende, D. F. C. (2009). Limites jurídicos da terapia gênica embrionária: por uma reconstrução crítico-discursiva dos direitos da personalidade (Dissertação de mestrado, Pontifícia Universidade Católica de Minas 
Gerais, Programa de Pós-Graduação em Direito. Belo Horizonte, Minas Gerais, Brasil.

Rodotà, S. (2010). La vida y las reglas: entre el derecho y el no derecho. Madrid: Trotta.

Rodrigues, Léo. (2012). O atleta transgênico: possibilidade real de uso do doping genético divide pesquisadores: endurecer ou flexibilizar as regras? Disponível em: https:// www.ufmg.br/diversa/19/esportes.html.

Sá, M.F. F. e Naves, B. T. O. (2004). Bioética, Biodireito e o novo Código Civil de 2002. Belo Horizonte: Del Rey.

Sá, M. F. F. e Naves, B. T. O. (2011). Manual de biodireito $\left(2^{\circ} \mathrm{ed}\right.$.). Belo Horizonte: Del Rey.

Santos, M. C. C. L. (2001). Limites éticos e jurídicos do projeto genoma humano. Em: Santos, M. C. C. L., Biodireito: ciência da vida, os novos desafios (pp. 306-325). São Paulo: Ed. Revista dos Tribunais.

Semião, S. A. (2012). Biodireito \& direito concursal: aspectos científicos do direito em geral e da natureza jurídica do embrião congelado. Belo Horizonte: Del Rey.
Stancioli, B. e Carvalho, N. P. (2011). Da integridade física ao livre uso do corpo: releitura de um direito da personalidade. Em: Teixeira, A. C. B. \& Ribeiro, G. P. L., Manual de teoria geral do direito civil (pp. 267-285). Belo Horizonte: Del Rey.

Tavares, F. H., Franco, L. R., Couto, C. P. S., Pádua, C. B. M., Dinalli, D. J., Librelon, K. F... (2009). Bioética e Biodireito. Virtuajus: Revista Eletrônica da Faculdade Mineira de Direito da PUC Minas. Disponível em: http://www.fmd.pucminas.br/Virtuajus/2_2009/Docentes/Bioetica\%20e\%20Biodireito.pdf.

Vasconcelos, C. (2012) Os impactos da biotecnologia no esporte. Em: Jordão, M. (Coord.) Instituto De Direito Desportivo Da Bahia. Instituto Mineiro De Direito Desportivo. Direito desportivo e esporte:volume 3: temas selecionados. pp.29-43.

Westman, J. A. (2006). Genética médica. Rio de Janeiro: Guanabara Koogan. 
